\title{
Social and private profitability of tree-based adaptation options to climate change in a dryland area of Tunisia
}

\author{
Hamed Daly-Hassen*, Mohamed Annabi ${ }^{\star}$, Caroline King-OKumu ${ }^{\star *}$
}

DOI: $10.30682 / \mathrm{nm} 1902 \mathrm{f}$

JEL codes: O13, O55

\begin{abstract}
Climate change exacerbates the effects of water scarcity on livelihoods. Governments can intervene by structuring incentives for agricultural adaptations so that farmers can choose the ones that create more benefits for the society as a whole. This requires consideration of a range of different benefits to different groups within the social cost-benefit analysis (CBA). We assess the social and private profitability of two alternative tree-based adaptation techniques that have received state support in the traditional barley cropping/rangeland systems in Central Tunisia: olive tree plantation, and intercropping with cactus. The results showed that society does not benefit from offering incentives for olive production. The production of irrigated olive trees without incentives is profitable for farmers and for society, while rainfed plantation is not profitable at all. However, it is possible for farmers to increase their incomes without increasing agricultural water use if they are encouraged to adopt intercropping with cactus to supplement livestock food and watering. The findings highlight scope for policies to balance between returns both for society, and for farmers, as revealed through the application of quantitative social CBA.
\end{abstract}

Keywords: Tunisia, Cost benefit analysis, Water scarcity, Olive tree, Cactus.

\section{Introduction}

Water scarcity in the Mediterranean area is expected to worsen under potential climate change (CC) predictions (IPCC, 2014). Across the region, research and extension services are exploring how technology transfers can enable farmers to adapt (Alrusheidat et al., 2016). In Tunisia, CC adaptation (MESD, 2015) is based on a projected increase in average temperature of $2.1^{\circ} \mathrm{C}$ and a decrease in annual rainfall by $20 \%$ in 2050 (GIZ, 2007; Lhomme et al., 2009; Bird et al., 2016). Climate changes have been affecting the livelihoods of the low income households depending on family farming in central and southern parts of the country (Verner and Breisinger, 2013; Zouabi and Peridy, 2015; Ben Zaied and Zouabi, 2016). Further discussion of the potential strategies for agricultural sustainability under climate change and increasing water scarcity in Tunisia is presented in Zouabi and Peridy (2015).

Decision makers' interventions are intended to improve the outcomes of climate change adaptation for vulnerable communities, and for the society as a whole. However, policy failures can occur due to the lack of information and/or

\footnotetext{
* National Agricultural Research Institute of Tunisia, Carthage University, Tunisia.

** The Borders Institute, Kenya \& GeoData Institute, University of Southampton, UK.

Corresponding author: Mohamed Annabi, mannabi@gmail.com
} 
uncertainty of the expected outcomes of the intervention strategies (Chambwera et al., 2014). Cost-benefit analysis of intervention strategies offers a means to overcome this bottleneck by encouraging rigourous analyses of decision alternatives (Kurukulasuriya and Rosenthal, 2013). However, one of the challenges encountered in applying cost-benefit analyses is that public and private perspectives on the relative magnitudes of the adaptation benefits and costs may vary (Hanley and Barbier, 2009).

Across much of the mediterranean region, the conversion of natural pastures and rangeland areas to commercial tree production (including olive plantations has been driven by demands from international markets (Zdruli, 2014). Agroforestry and sylvopastoralism have often been proposed as a means to solve, or at least to mitigate, problems related to land degradation (Le Houérou 1990, 2000). Under ongoing climate changes across the rangelands, it has been argued that investments in agroforestry offer a means to avert widespread disruption of socio-economic well-being (FAO, 2005; Lasco et al., 2014). Trees are recognized to contribute to microclimate regulation in dry areas. They can reduce evaporative water loss from the soil surface, and thereby enhance water use efficiency, soil fertility, vegetation productivity and carbon sequestration (Braimoh, 2012; Gracia et al., 2011).

Various contributions to the international development literature have considered the private costs and benefits of investments in the production of olives (Stilitano et al., 2016; Sgroi et al., 2015; Mohamad et al., 2014), cactus fodders (Guevara et al., 1999a, 1999b) and agroforestry more broadly (e.g. Barbier, 2000; Alavalapati and Mercer, 2005). But very few have investigated the full social returns and costs of these investments in $\mathrm{CC}$ adaptation in rangeland communities and their livelihood systems (exceptions include: Lasco et al., 2014; Paul et al., 2017). No assessment of the likely returns on investments in agroforestry has yet succeeded to integrate understanding of the complexity of these systems with an economic assessment of effects under climate change and increasing water scarcity.

Decision-makers and extension services have supported tree-based adaptations as a means to reduce the ecosystem vulnerability and stabilize farmers' incomes in Southern Tunisia. Olive plantation is subsidized because it provides farmers with an additional and diversified source of income in the medium term (Sghaier et al., 2010; Ben Zaied and Zouabi, 2016). But over the longer term, in the context of increasingly scarce and variable rainfall due to $\mathrm{CC}$ there is a real concern that these tree crops will result in greater demand for supplemental irrigation, and so exacerbate water scarcity (Mohamad et al., 2014; Alfieri et al., 2018). In the Northern Mediteranean, it is estimated that each litre of extra virgin olive oil production already requires 3900 litres of irrigation water, delivered using $433.6 \mathrm{~g}$ of fuel (Banias et al., 2017).

Cactus production is another tree-based adaptation option also aready supported by government and extension services (Alary et al., 2007). Cactus grows faster than olive, and cactus cladodes can be used as an alternative feed supplement and water source for livestock. Cactus plantation is considered helpful to combat soil erosion in the rangelands (Mazhar et al., 2002). Furthermore, it requires less water and is more drought tolerant than other tree-based adaptation options, such as growing olive trees. Recently, high economic value attributed to prickly pear fruits and seed oil has been observed as a lucrative benefit that can be achieved while promoting the recovery of native vegetation (Genin et al., 2017).

The objective of this study is to assess the economic profitability of the two identified treebased adaptation techniques in the rangelands of central Tunisia under the changing climate. Following a brief conceptual review of the economic assessment approach, the study area and adaptation techniques (olive trees and cactus) are introduced.

Following the presentation of the methods and results obtained (both quantitative and qualitative), a concluding discussion explores the significance of the findings for decision-making in Tunisia. The discussion then reflects on the interest of the study to the international scientific community, in light of the continued emphasis on tree-based adaptation options for rangeland areas across various parts of Africa, particularly south Mediterranean countries. 


\section{Economic assessment approach}

The economics of agricultural adaptation practices under $\mathrm{CC}$ have been investigated in a range of contexts (Chambwera et al., 2014; Trærup and Stephan, 2015; Watkiss et al., 2015), These adaptation practices generate both off-site as well as on-site effects (Fleskens et al., 2005). Off-site effects occur in hydrological systems (e.g. through changing groundwater recharge) or climate regulation (e.g. through effects on emission and sequestration of $\mathrm{CO}_{2}$ ). On-site effects are related to land productivity. Different stakeholders may assign different values and priorities to on-site and off-site benefits and costs (Chaudhury et al., 2016). Farmers are most interested in reducing on-farm costs, maximizing net returns, and reducing risk. On the other hand, public sector interest is more oriented to the social benefits including off-site effects on shared resources such as water and ecosystems (Hanley and Barbier, 2009). At the global level, the major interest is mitigation of greenhouse gas emissions to minimize $\mathrm{CC}$ and associated negative effects (World Bank, 2010).

$\mathrm{CC}$ adaptation is mainly implemented at the individual level. The private costs and benefits of production in the barley-rangeland-livestock systems are complex, due to multidimensional farm budgets, including both crop and livestock production. Surveys can help to shed light on these (e.g. Alary et al., 2005). Governments can offer incentives for adaptations that will generate social benefits as well as private benefits (Sgroi et al., 2015). Analysis of both public and private costs and benefits can help to identify win-win strategies (Daly-Hassen et al., 2010; Branca et al., 2015).

Farm surveys can shed light on the private costs and benefits of adaptation. However, to take social costs and benefits into consideration, an additional layer of complexity is included to the cost-benefit analysis. Effects on water scarcity may have a growing significance for society, but understanding these requires additional use of environmental and climate modeling techniques (building on GIZ, 2007). Policy analysts must then combine their knowledge of the outputs from these models with understanding of the production systems and society to assess the likely economic effects of adaptation decision-making (as in Verner and Breisinger, 2013; Grami and Ben Rejeb, 2015).

\section{Materials and Methods}

\subsection{Study site caracteristics}

The dominant social and livelihood systems in the central and southern rangelands of Tunisia rely on small ruminant production in barley-rangeland-livestock systems (Jemaa et

Table 1 - Characteristics of households extracted from the statistical analysis of the 2013-survey ( $\mathrm{n}=100$ farmers).

\begin{tabular}{|l|c|c|c|c|c|}
\hline & Mean & Median & $\begin{array}{c}\text { Standard } \\
\text { deviation }\end{array}$ & Minimum & Maximum \\
\hline Age & 54 & 53 & 15.7 & 23 & 90 \\
\hline Size of household & 7.8 & 8.0 & 3.3 & 1 & 22 \\
\hline Surface area (ha) & 14.7 & 10 & 14.6 & 0 & 70 \\
\hline Barley (ha) & 3.5 & 3.0 & 3.73 & 0 & 22 \\
\hline Wheat (ha) & 2.7 & 2.0 & 2.85 & 0 & 20 \\
\hline Forage (ha) & 0.24 & 0 & 0.64 & 0 & 3 \\
\hline Fallow (ha) & 2.38 & 0 & 6.16 & 0 & 34.66 \\
\hline Pasture (ha) & 1.81 & 1 & 2.55 & 0 & 14.5 \\
\hline Cactus (ha) & 1.92 & 1 & 2.19 & 0 & 10 \\
\hline Olive trees (ha) & 2.84 & 2.12 & 3.40 & 0 & 30 \\
\hline Vegetables (ha) & 0.05 & 0 & 0.41 & 0 & 4 \\
\hline Number of sheep & 26 & 20 & 22 & 0 & 100 \\
\hline
\end{tabular}


al., 2016). Rainfed crop productivity can decrease by $80 \%$ in drought years, and increase by $10 \%$ in wet years (GIZ, 2007). In addition to effects on human populations and irrigated production, water scarcity and salinization also has negative effects on livestock productivity (MAF, 2004). Lack of alternative economic activities, periodic droughts, and rangeland degradation have led farmers to adapt by irrigating new cash crops, using supplemental irrigation to support rainfed production, and purchasing concentrated feeds for their livestock (Ouled Belgacem and Louhaichi, 2013). Based on the data survey, on average, a household owns about 15 ha and has 26 sheep (Table 1) that may achieve an income of 5161 dinars per year in 2013.

The study was conducted at the Zoghmar village, Sidi Bouzid governorate, central Tunisia $\left(35^{\circ} 22^{\prime} 32^{\prime \prime} \mathrm{N} 9^{\circ} 21^{\prime} 22^{\prime \prime} \mathrm{E}\right)$ (Fig. 1). The study site covers 2,435 ha, the population was 2371 in 2013, spread amongst 413 households (INS, 2012). The unemployment rate in the area is about $12 \%$. Houses are equiped with electricity and families collect water from public wells using cisterns. The main livelihood constraints identified by households are related to unemployment, weakness of financial resources, insufficient investment means, low level of edu- cation, lack of opportunities for young people, low salaries for women in agricultural fields, lack of drinking and irrigation water, and drought. Recognized opportunities to improve livelihoods include: distribution of drinking water, creation of new irrigated areas, plantation of cactus, and soil and water conservation.

The climate is semi-arid with a mean annual temperature of $19^{\circ} \mathrm{C}$ and mean annual rainfall of $241 \mathrm{~mm}$ (INS, 2012). The average annual evapotranspiration is about $1500 \mathrm{~mm}$. The drought frequency is 6 years in a decade. For water resources, three hill lakes in the upper reaches of the Hajeb-Jelma watershed collect runoff water, and various structures have been installed in the watershed to enhance groundwater recharge. In addition, two deep wells, made available to small farmers through a local farmers' association, are used for both drinking and irrigation water (GIZ, 2012).

Transhumance has practically disappeared from the small ruminant-cereal cropping-barley systems in Zoghmar but some collective rangelands are still present. Livestock have always been essential to the viability of agricultural livelihoods in the study area. The livestock sector is strongly dependent on feed resources. This was not the case four decades ago, when the rangelands covered most of the

Figure 1 - Map of Tunisia showing the study area: Zoghmar village.

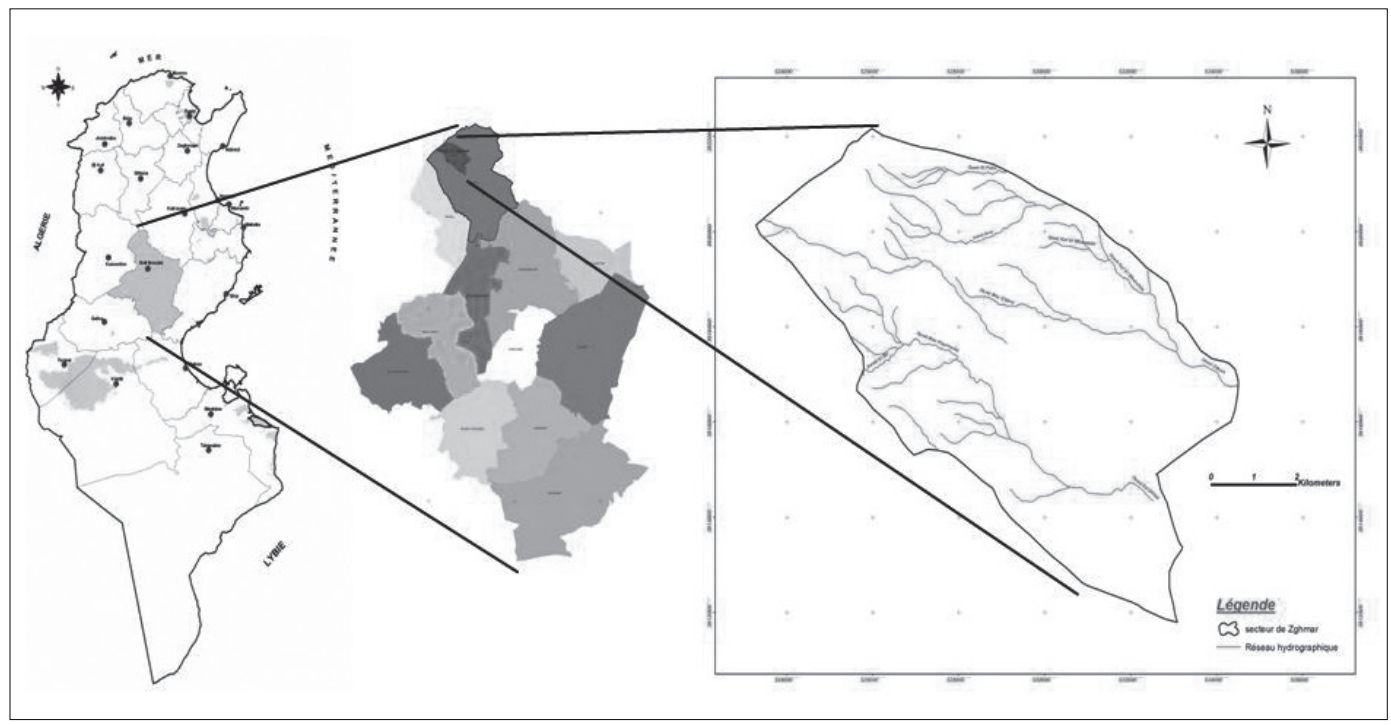


livestock feed requirements. Changes in production system patterns, observable in the past studies (INRAT, 1999; ICARDA, 2005) include increasing herd numbers and intensification of the production systems through irrigation and olive tree plantation.

The Office de l'Elevage et de Pâturages (OEP) is encouraging cactus plantations on private lands by covering some plantation costs and providing compensation for income loss from grazing in these plantations (45 TND/ha per year) during the first three years. Technical support for irrigation improvement and/or promotion of additional alley cropping with cactus appeared to the agricultural research and extension services to be the most feasible options for adaptation to climate change to be supported by the government. Olive tree plantation is practiced by famers in rainfed and irrigated areas. Also, the state offers a subsidy of $60 \%$ toward the cost of irrigation equipment.

\subsection{Future climate trend and calculation of additional irrigation water demand}

Climate forecasts for Sidi Bouzid according to the HadGEM2-ES for CRP 4.5 model, indicate a $16 \%$ decrease in annual rainfall anticipated by 2050-2060, and a $0.9^{\circ} \mathrm{C}$ increase in average annual temperature. While there are uncertainties, there is no doubt that the suitability of agricultural land for cereal crops will be reduced to a marginal suitability level.

Crop water demands were estimated according to the downscaled HadGEM2-ES results for RCP 4.5 emission scenario included into the Marksim ${ }^{\mathrm{TM}}$ for CMIP5 weather file generator (Jones and Thornton, 2013). The amount of additional water needed for irrigation was calculated in accordance with the change of evapotranspiration (FAO, 1998) with the predicted CC scenario.

\subsection{Economic data}

A survey was conducted from October to November 2013, in Zoghmar village to assess current private costs of and benefits for different land uses. The questionnaire was admin- istered randomly to a stratified sample of 100 households (about one fourth of the farming households) distributed amongst the different production systems, farm types and zones in the eight communities living in the study area. Main farm types considered are agropastoral farms, small and middle-sized crop-livestock farms and diversified farms in irrigated areas (Alary et al., 2007).

Three previous surveys informed the survey design and provided information on the landuses and livelihoods of people in the study area (INRAT, 1999; ICARDA, 2005). Similar to the previous surveys, the respondents interviewed were introduced as the heads of households (all of them male) who indicated that they made the decisions and managed the farms. These surveys also provided baseline information for identification of land use changes.

The survey was based on face to face interviews on site. Questions were related to physical and economic characteristics in order to determine costs and benefits of different crops and livestock production. After some general information about land ownership and uses, the first part of the questionnaire focused on costs and benefits from different crops or sylvopastoral plantation (cereals, olive trees, cactus), livestock production and the income generated from non-agricultural activities. The second part dealt with the effects of climate on crop yield, land use and measures for adaptation. A limited number of qualitative observations were requested about perceptions of $\mathrm{CC}$ risks and adaptation.

\subsection{Cost-benefit analysis (CBA) of adapta- tion options}

Rangelands and rainfed barley cropping were considered as baseline (B), whereas the two alternative adaptation options (A) involved either olive trees or cactus plantation. In irrigated areas where irrigated barley production is practiced, irrigated olive tree plantation was studied as an adapation option consuming less water than barley. Irrigation is restricted to a small area due to limited water supply from three hill lakes and two deep wells. 
CBA is a decision support tool that gives economic information to allocate scarce resources (Hanley and Barbier, 2009). The CBA elaboration for the tested adaptation options consists in:

(i) Assessment of present costs and benefits from the farmer perspective. This included identification and collection of data enabling quantification of costs and benefits in 2013, including the on-farm income in terms of the net benefit per hectare,

(ii) Assessment of present costs and benefits from the perspective of the national society and global community,

(iii) Projection of the same indicators and values over the life duration period, including anticipated CC (but no other change related to productive activities or prices),

(iv) Assessment of the Net Present Value (NPV) and the Internal Rate of Return (IRR) of the alternative adaptation options, using appropriate discount rates.

Costs and benefits in 2013 for each production pattern (crops or sheep) were assessed in order to determine the net private benefit as follows:

Net private benefit $=$ Revenue at market price

- Total cost at market price

With:

Revenue $=\sum$ Quantity $*$ Price

Total cost $=$ input cost + labor cost + other costs

Input cost $=\sum \mathrm{Q} \times \mathrm{P}$ (water, seeds, fertilizers, chemicals, hay, concentrate, straw, pasture...) Labor cost $=$ Number*Wage

Other costs $=\sum \mathrm{C}$ (pilling, harvesting, veterinary, maintenance, transport, depreciation...)

From the social and global perspectives, economic costs and prices are introduced (Hagen, 2009), instead of financial costs and prices, as follows:

Net social benefit $=$ Net benefit of the production on site - Cost of water degradation

Net global benefit $=$ Net benefit of the production on site - Cost of water degradation + Value of carbon sequestration

\subsection{Net Present Value and the Internal Rate of Return (IRR)}

The Net Present Value (NPV) corresponds to the sum of present values (PV) of net benefit flows. The PV is estimated using an annual discount rate $r$ as follows:

$$
\mathrm{NB}_{\mathrm{i}} /(1+\mathrm{r})^{\mathrm{i}} \text { for the year i }
$$

The IRR corresponds to the discount rate " $r$ " at which the NPV is nul. The adaptation option is worthwhile if the NPV is positive when discounted at a suitable discount rate and IRR is higher than the opportunity cost of capital. Generally, an option with a higher NPV would be preferred. If the NPV is negative for farmers but positive from the social perspective, this means that the adaptation option is beneficial for the society, because of its high environmental benefit. In this case, a subsidy to farmers might be justified.

The NPV is calculated for a period of 20 years for cactus (OEP, Personal communication) and of 60 years for olive trees plantation (Stillitano et al., 2016) that corresponds to their economic life span, allowing regular and good level of production. In Tunisia, cost-benefit assessments made by decision-makers do not usually consider effects on water scarcity and a discount rate of $10 \%$ is most often applied. In this study, a discount rate of $8 \%$ is considered for both farmers and society. Lower discount rate (from 1 to $4 \%$ ) has been recommended for projects affecting natural capital and climate change, as the availability of this resource in the future cannot be guaranteed (Stern, 2006; TEEB, 2010). Threfore, a sensitivity analysis was conducted using a discount rate of $2 \%$.

\section{Results}

\subsection{Land use changes}

Survey results indicate that each household owns an average of 14.7 ha ( $42 \%$ cereals, $19 \%$ olive tree, $13 \%$ cactus, $23 \%$ fallow and pasture and $6 \%$ irrigated crops) (Table 1). Comparison of the survey results to those of previous surveys showed that the extent of the rangelands in 
Zoghmar had increased from 3\% in 2002 to $23 \%$ in 2013 and cereal cropping area had decreased from $85 \%$ in 1991 (INRAT, 1999) to $42 \%$ of the total agricultural surface area in 2013. The change can be attributed to the increasingly unfavourable climate.

All interviewed farmers consider $\mathrm{CC}$ as a threat for their income, a threat they're managing using irrigation and buying more food for the animals. Over the period 1991-2013 the adaptation was mainly by increasing the size of the livestock flocks from an average of 20 ewes per farm to 26 . New irrigated areas covered $6 \%$ of the total area in 2013. This was used mainly for vegetables, irrigated cereal production and olive tree orchards. The area under olive plantation had increased from $10 \%$ in 1991 to $19 \%$ of the surface area in 2013.

For the whole sample, the surface area of olive trees represents 285 ha, while the irrigated area is limited to 95 ha with a mean irrigation water applied of $2060 \mathrm{~m}^{3} /$ ha per year. In 2013, water from the two deep wells that were present in the target area reached less than $30 \%$ of the irrigated area. This was due to irrigation equipment shortages, poor mastering of the irrigation technology and the technical requirements for growing irrigated crops.

Cactus plantation in Zoghmar region increased during the period 1991-2013. The land area occupied by the cactus-crops (mainly barley) commonly known as alley-cropping had increased by $11 \%$ during the period 2002-2013. About $77 \%$ of farmers either own intensive cactus plantations (high plantation density) or have adopted cactus alley plantation.

\subsection{Climate change effects}

The available production baseline information was from the period 2002-2011 (CRDA). During this period, barley yields, recorded by the CRDA, ranged from 0 to $960 \mathrm{~kg} / \mathrm{ha}$, with a mean of $360 \mathrm{~kg} / \mathrm{ha}$ under rainfed conditions. These regional data, that cannot be collected through surveys or other physical measures, were used in order to take into account the an- nual variation of productivity in function of climate conditions. Over the period 2002-2011, the rangeland production was estimated by CRDA at $150 \mathrm{FU} / \mathrm{ha}$ on average using the same trends of barley (CRDA). Under rainfed conditions, the CC effect was estimated to result in a reduction of crop production by $0.5 \%$ per year. With irrigation, crops production was assumed to be constant.

Based on CC predictions about decrease of rainfall for 2050-2060 time slice and the additional irrigation water needs for olive trees estimated at $1000 \mathrm{~m}^{3} /$ ha per year, it was assumed that the rate of decline in the groundwater level would double.

\subsection{Assessment of additional costs of adap- tations}

Additional costs to the farmer and to the society (national and global) associated with the two adaptation alternatives were identified (Table 2).

\section{Costs of cactus plantation}

Based on the survey findings, the costs associated with cactus plantation and exploitation were identified to include: cactus cladodes, ploughing, and labour for plantation, guarding, grazing and harvesting of pads. No additional water was needed as an input to the cactus production. Social costs include all the costs used i.e. the value of family labor, cost of cactus plantation, and costs of cladodes and fruits collection. The large difference between the cost for farmers and the cost for society is due to public subsidies for cactus plantation, which are about 390 Tunisian Dinar $\left(\mathrm{TND}^{1}\right) /$ ha in total. These include the costs of cladodes, the cost of ploughing and some costs of plantation. The survey indicated that the only added cost for farmers to grow cactus is the cost of land preparation: deep-plowing for intensive plantation or plantation-line opening using a moldboard plow with $20 \mathrm{~m}$ distance.

\section{Costs of olive plantation}

The costs associated with olive plantation were identified to include costs for plantation,

11 Tunisian Dinar (TND) = \$ US 0.62 in 2013. 
Table 2 - Costs and benefits of cactus and olive tree plantations considered from farmer and social perspectives in 2013.

\begin{tabular}{|c|c|c|c|c|}
\hline & & Unit & Farmer & $\begin{array}{l}\text { Society/Global } \\
\text { community }\end{array}$ \\
\hline Costs & $\begin{array}{l}\text { Cactus } \\
\text { Cactus cladodes } \\
\text { Ploughing } \\
\text { Labor for plantation } \\
\text { Guarding } \\
\text { Labor for grazing } \\
\text { Pads harvesting }\end{array}$ & $\begin{array}{l}\text { TND.ha-1 }^{-1} \\
\text { TND.ha } \\
\text { TND.ha- } \\
\text { TND.ha' } \\
\text { TND.FU' } \\
\text { TND.t }\end{array}$ & $\begin{array}{l}- \\
- \\
30 \\
- \\
- \\
-\end{array}$ & $\begin{array}{l}200 \\
40 \\
150 \\
15 \\
0.16 \\
10\end{array}$ \\
\hline & $\begin{array}{l}\text { Olive tree } \\
\text { Plantation } \\
\text { Water irrigation (initial implementation, rainfed) } \\
\text { Water equipment (irrigated) (each } 5 \text { years) } \\
\text { Water for irrigation (irrigated) (per year) } \\
\text { Plowing (per year) } \\
\text { Pruning (each } 2 \text { years) } \\
\text { Olive harvesting (per year) } \\
\text { Additional cost of water degradation (per year) }\end{array}$ & $\begin{array}{l}\text { TND.ha- }{ }^{-1} \\
\text { TND.ha }^{-1} \\
\text { TND.ha- } \\
\text { TND.ha- } \\
\text { TND.ha } \\
\text { TND.ha- } \\
\text { TND. } \\
\text { TND. }{ }^{-1} \\
\text { TND.ha- }\end{array}$ & $\begin{array}{l}386 \\
390 \\
464 \\
250 \\
72 \\
50 \\
150 \\
-\end{array}$ & $\begin{array}{l}466 \\
345 \\
1160 \\
624 \\
72 \\
50 \\
150 \\
2.8\end{array}$ \\
\hline Benefits & $\begin{array}{l}\text { Cactus } \\
\text { Compensation (three first years) } \\
\text { Value of pads and fruits (from } 4^{\text {th }} \mathrm{yr} \text { ) } \\
\text { Value of forage (from } 4^{\text {th }} \mathrm{yr} \text { ) } \\
\text { Carbon sequestration }\end{array}$ & $\begin{array}{l}\text { TND.ha }{ }^{-1} \cdot \mathrm{yr}^{-1} \\
\text { TND.ha }{ }^{-1} \cdot \mathrm{yr}^{-1} \\
\text { TND.ha }{ }^{-1} \cdot \mathrm{yr}^{-1} \\
\text { TND. } \mathrm{t}^{-1} \mathrm{CO}_{2}\end{array}$ & $\begin{array}{l}45 \\
218.4 \\
57.8 \\
-\end{array}$ & $\begin{array}{l}- \\
231.9 \\
73.7 \\
6.6\end{array}$ \\
\hline & $\begin{array}{l}\text { Olive tree } \\
\text { Olives } \\
\text { Fuel wood } \\
\text { Carbon sequestration }\end{array}$ & $\begin{array}{l}\text { TND. } t^{-1} \\
\text { TND. } t^{-1} \\
\text { TND. } t^{-1} \mathrm{CO}_{2}\end{array}$ & $\begin{array}{l}710 \\
40 \\
-\end{array}$ & $\begin{array}{l}710 \\
40 \\
6,6\end{array}$ \\
\hline
\end{tabular}

irrigation, plowing, pruning and harvesting. There is a difference between financial cost of labor (for the farmer) and the economic cost (where the cost of family labor is included). The plantation costs were $386 \mathrm{TND} / \mathrm{ha}$ for the famer and $466 \mathrm{TND} /$ ha for the society. The costs to the farmer for irrigation include irrigation equipment and cost of water for irrigation. The water equipment is subsidized by $60 \%$. A tariff is applied for water for irrigation (0.12 TND per $\left.\mathrm{m}^{3}\right)$ in the irrigated area that covers mainly the costs of maintenance of infrastructure and fuel for pumping. The cost of water applied for filling cisterns and used for the irrigation in rainfed area is much higher $\left(0.6\right.$ TND per $\left.\mathrm{m}^{3}\right)$.

From a social perspective, the cost assessment should consider the full cost of water, including the opportunity cost (additional value foregone to society for an additional unit of water). In light of the value of foregone agricultural productivity, this was calculated at: 0.3 TND. ${ }^{-3}$ in 2013. As a result, the cost of water to farmers in the irrigated area (250 TND/ha) is below the economic value of water (624 TND/ha). For society, an additional cost of irrigation water is due to the costs of negative externalities (water degradation, i.e.: decline in groundwater level).

To assess the cost of water use in light of offsite effects on the water table, and the additional cost of the adaptation to increase irrigated olive production, we consider groundwater extraction costs using the replacement cost method (Hellegers et al., 2001). This is assessed through the cumulative additional cost of water pumping over time (Figure 2). The decline in the water table is assumed to continue at a linear rate in the 


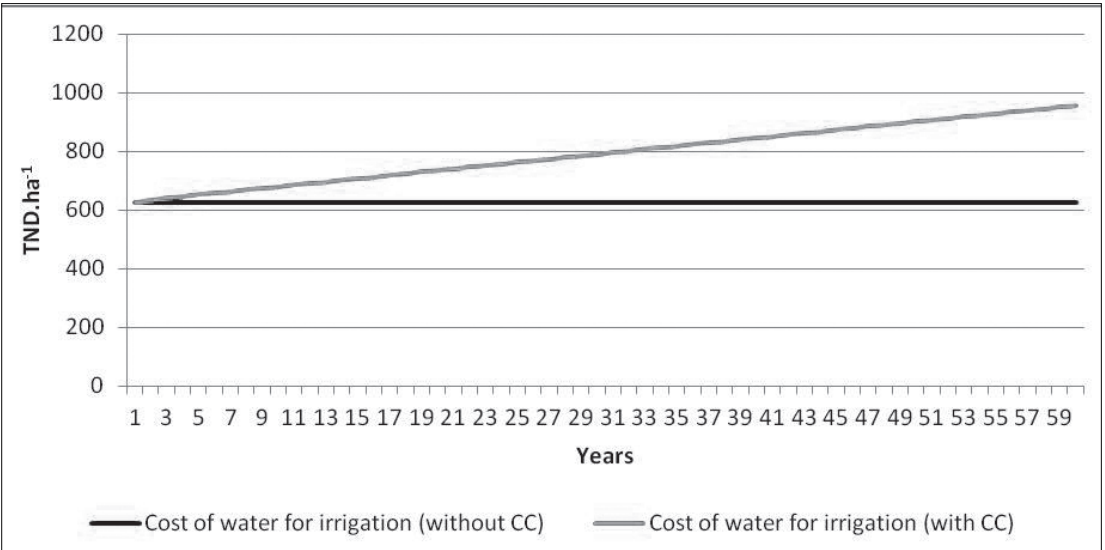

Figure 2 - Effect of the climate change on the cost of water for irrigation. future, resulting in a decrease of $0.7 \mathrm{~m}$ per year. The cost of water pumping would rise accordingly. Under CC and crop water demand will increase, groundwater recharge will decrease and groundwater levels will decline faster. Increasing irrigated olive plantation accelerates increasing water demand, extraction and lowering of the groundwater table. This increases the costs to society to access water supplies.

\subsection{Assessment of benefits}

\section{Benefits of cactus plantation}

Herd owners using cactus pads for sheep feeding ( 85 farms) have an average of 2.7 ha of cactus to satisfy their needs. The survey indicated that the use of cactus pads enables savings on livestock feed and water costs, so that the total production costs were lower (-9 TND per ewe, on average). The improved nutrition and watering of the sheep increased their sale value by +40 TND per ewe, on average. The annual use of cactus pads was $6.3 \mathrm{t} / \mathrm{ha}$ (alley cropping) and $7.8 \mathrm{t} / \mathrm{ha}$ (whole plantation). The same production rate is assumed for cactus from age 4 to age 20 , which is the average life duration of cactus shrubs (Ben Salem, 2014).

For the society, benefits from cactus include the value of cladodes as an energy source for livestock $(1 \mathrm{~kg}$ fresh matter $=0.065$ Forage Units: FU) and the value of fruits collected, estimated at the local market price. Benefits include both cactus pads collected and used for sheepfeed, and pads and fruits sold in the market. The market price of pads and fruits are 0.03 and 0.1 $\mathrm{TND} / \mathrm{kg}$, respectively. On a per hectare basis, the additional net benefit of cactus is $218 \mathrm{TND} /$ ha (Table 2). The shadow price of barley, based on import price, is used for assessing the social value of the forage unit $(0.49 \mathrm{TND} / \mathrm{FU})$. The local price of forage (value to the farmer) is less than the social value.

For cactus, carbon sequestration was estimated at $0.3 \mathrm{t} / \mathrm{ha}$ and $1.9 \mathrm{t} / \mathrm{ha}$ respectively for young plantation and for old plantation. The underground biomass is estimated as $40 \%$ of above ground biomass. These estimates are quite approximated and information about carbon sequestration in soils is unavailable in the study area. These assumptions could be replaced with more refined estimates if decision-makers would chose to invest in the scientific work required.

The price of carbon sequestration on the international market is \$ 4 per ton of $\mathrm{CO}_{2}$ (Hamrick and Goldstein, 2016). This price could increase with the evolution of carbon pricing instruments. It should be noted that prices vary between 1 $\$$ and $130 \$$ per ton of $\mathrm{CO}_{2}$, depending on the instruments, and are less than $\$ 10$ per ton of CO2 for $85 \%$ of emissions (Kossoy et al., 2015). In the absence of clear future projections, it is assumed that this price will remain constant in future, as a conservative value. We also assume that all other prices will remain constant.

\section{Benefits of olive trees plantation}

Olive groves in Zoghmar have a life duration of 60 years, a density of plantation of 100 trees/ 
ha and a survival rate of $90 \%$. Barley is intercropped between olive tree lines only for the first five years after olive tree plantation. Management costs include plowing, irrigation (for 10 years in rainfed plantation) and trimming. In the rainfed plantations, the yield production of olives is considered similar to those observed in the period 2002-2011 (ranged from 0.04 to $0.71 \mathrm{t} / \mathrm{ha}$, CRDA data), whereas, a progressive increase is anticipated in the irrigated area from year $3(0.5 \mathrm{t} / \mathrm{ha})$ to year $7(2.5 \mathrm{t} / \mathrm{ha})$ and a production varying between 2.75 and $3.50 \mathrm{t} / \mathrm{ha}$ is expected (from year 8).

The benefits do not integrate only olive production, but also, fuel wood production (40 $\mathrm{TND} / \mathrm{t}$ ) since the half of the above olive trees biomass is pruned each two years after harvesting.

Carbon sequestration by olive trees is determined according to the volume of biomass production and the olive tree pruning. This depends on the age of vegetation: for olive trees, it is estimated to be from $0.2 \mathrm{t} / \mathrm{ha}$ at the age of 1 year to $7.5 \mathrm{t} / \mathrm{ha}$ at 20 years and beyond under irrigated systems (Nefzaouí and Zidani, 1987). It is assumed that half of this quantity is acheived by olive trees under rainfed conditions and that pruning induces a reduction by half the quantity of carbon sequestred, resulting from cutting half of the biomass (Ben Rouina et al., 2007).

\subsection{Profitability of different adaptation op- tions}

Once costs and benefits of cactus and olive tree plantations were identified for the life duration, a cost-benefit analysis was undertaken for assessing their profitability.

\section{Introducing cactus to barley or rangeland systems}

Cactus plantation was profitable from both the farmers' perspective and the social perspective (Table 3).

With the subsidies and compensation for income losses, cactus plantation becomes very encouraging for farmers. From the farmers' perspective, cactus-barley alley cropping provided greater NPV (8\%, 20 years) of $2457 \mathrm{TND} /$ ha than barley alone (607 TND/ha), inducing an additional value of $1850 \mathrm{TND} /$ ha (Table 3 ). The gap between the return on cactus plantation

Table 3 - Comparison of the Net present value (NPV in TND.ha ${ }^{-1}$ ) between baseline (B) and adaptation options (A).

\begin{tabular}{|c|c|c|c|c|c|c|}
\hline & \multicolumn{2}{|c|}{$\begin{array}{l}\text { From farmer } \\
\text { perspective }\end{array}$} & \multicolumn{2}{|c|}{$\begin{array}{l}\text { From national } \\
\quad \text { society }\end{array}$} & \multicolumn{2}{|c|}{$\begin{array}{l}\text { From global } \\
\text { perspective }\end{array}$} \\
\hline$N P V$ & Values & Gains & Values & Gains & Values & Gains \\
\hline \multicolumn{7}{|c|}{ Discount rate: $8 \%$, cycle of production $=20$ years period } \\
\hline B: Rangelands & 549 & & 465 & & 465 & \\
\hline B: Rainfed barley & 607 & & 122 & & 122 & \\
\hline A: Cactus & 1792 & +1243 & 909 & +444 & 1165 & +700 \\
\hline A: Cactus in alley / rangelands & 2247 & +1698 & 874 & +409 & 1130 & +665 \\
\hline A: Cactus in alley with barley & 2457 & +1850 & 1038 & +916 & 1294 & +1172 \\
\hline \multicolumn{7}{|c|}{ Discount rate: $8 \%$, cycle of production $=60$ years period } \\
\hline B: Irrigated barley (without CC) & 8721 & & 5201 & & 5201 & \\
\hline $\begin{array}{l}\mathrm{A}_{1} \text { : Irrigated olive tree plantation } \\
\text { (without } \mathrm{CC} \text { ) }\end{array}$ & 10921 & +2200 & 6183 & +982 & 6996 & +1795 \\
\hline $\begin{array}{l}\mathrm{A}_{2} \text { : olive tree plantation }+ \text { additional } \\
\text { irrigation due to } \mathrm{CC}\end{array}$ & 10492 & & 5069 & & 5881 & \\
\hline $\begin{array}{l}\mathrm{A}_{3}: \text { olive tree plantation }+ \text { additional } \\
\text { irrigation }+ \text { water table decline }\end{array}$ & 10492 & & 4582 & & 5394 & \\
\hline
\end{tabular}


and that generated by the natural rangelands or rainfed barley is likely to increase with ongoing climate changes that induce a reduction of the productivity of rangelands and rainfed barley. From the social perspective, the IRR for the cactus plantation in rangelands varied between $16 \%$ (cactus in alley cropping with rangelands) and $30 \%$ (cactus in alley cropping with barley). Nevertheless, the average values hide disparities in profitability depending on the intensity of use of cactus pads. Since the annual use of cactus cladodes ranges between 1.5 and $30 \mathrm{t} / \mathrm{ha}$, the NPV of alley plantation of cactus in rangelands can vary from -396 to $6903 \mathrm{TND} / \mathrm{ha}$. From the global perspective, the additional NPV is much higher than previous one for all types of cactus plantation (Table 3).

This study has confirmed that cactus and barley cropping generates an income for farmers when combined with sheep production. These additional benefits from cactus production are not as readily quantifiable because they require understanding of farm budgets integrating both crop and livestock production, rather than simply for crop production alone.

It should be considered that these economic results depend on the use of the cactus for feeding and climatic and agronomic risks. Alary et al (2007) conducted a CBA study at national level without considering social and environmental impacts. Using 2000 prices and data at national level, Alary's results show that the mean Internal rate of return (IRR) is $4.1 \%$ for the barley-cactus system and $4.7 \%$ for the pasture-cactus system, with a high sensitivity of the IRR according to risks considered ranging from $-1 \%$ to $+16 \%$.

\section{Introducing olive tree to barley or rangeland systems}

Rainfed olive tree plantation in Zoghmar is not profitable, neither from the farmer perspective nor from the social and global perspectives (Table 4). Farmers suffer losses of -904 TND/ ha for the first year of olive tree plantation and generate low gains from mature productive plantations (Figure 3). The IRR is estimated at $0 \%$ from the farmer perspective and $1.3 \%$ from the social perspective. When interviewed, farmers were aware of the losses that they could incur. They justified their decisions to maintain olive plantations in the rainfed areas for various reasons: anticipated future extension of irrigated area, preventing grazing by other herds, or increasing the land value. These reasons are similar to those reported previously by Guillaume (2009): change of in land ownership and socio-cultural dimension of olive trees as heritage value.

Olive trees will likely become increasingly dependent on irrigation water from dwindling reserves of groundwater. In irrigated areas, olive tree plantation is profitable (Table 3 and 4), with an IRR of $14.5 \%$ for farmers, $10.8 \%$ from the social perspective and $13.4 \%$ from the global perspective. The social cost for water is much higher than the cost to the private farmer (Table $2)$. Nevertheless, the net benefit from a young plantation $(<15$ years $)$ is low $(+246 \mathrm{TND} / \mathrm{ha}$ per year), but it increases for productive olive tree plantation (746 TND/ha per year) on average.

Using a low discount rate (of $2 \%$ ), the additional NPV varies considerably (Table 4), but remains unchangeable for the farmer and social perspectives.

Table 4 - Additional net present value of olive trees plantation at farmer, national society and global community perspective (Discount rates: $8 \%$ and $2 \%$, Life duration: 60 years).

\begin{tabular}{|l|c|c|c|c|c|c|c|}
\hline \multirow{2}{*}{$\begin{array}{l}\text { Baseline } \\
\text { production } \\
\text { system }\end{array}$} & $\begin{array}{c}\text { Adaptation } \\
\text { option }\end{array}$ & $\begin{array}{c}\text { Additional NPV from } \\
\text { farmer perspective } \\
\left(T N D . h^{-1}\right)\end{array}$ & $\begin{array}{c}\text { Additional NPV for } \\
\text { society perspective } \\
\left(T N D . \text { h }^{-1}\right)\end{array}$ & $\begin{array}{c}\text { Additional NPV from } \\
\text { global perspective } \\
\left(T_{N}\right.\end{array}$ \\
\cline { 3 - 8 } & & $8 \%$ & $2 \%$ & $8 \%$ & $2 \%$ & $8 \%$ & $2 \%$ \\
\hline Rangelands & Rainfed olive tree & -2949 & -2917 & -2656 & -2324 & -2223 & -633 \\
\hline Rainfed barley & Rainfed olive tree & -3625 & -4790 & -2382 & -1504 & -1949 & +187 \\
\hline Irrigated barley & Irrigated olive tree & 2200 & 13766 & 982 & 9810 & 1794 & 12988 \\
\hline
\end{tabular}




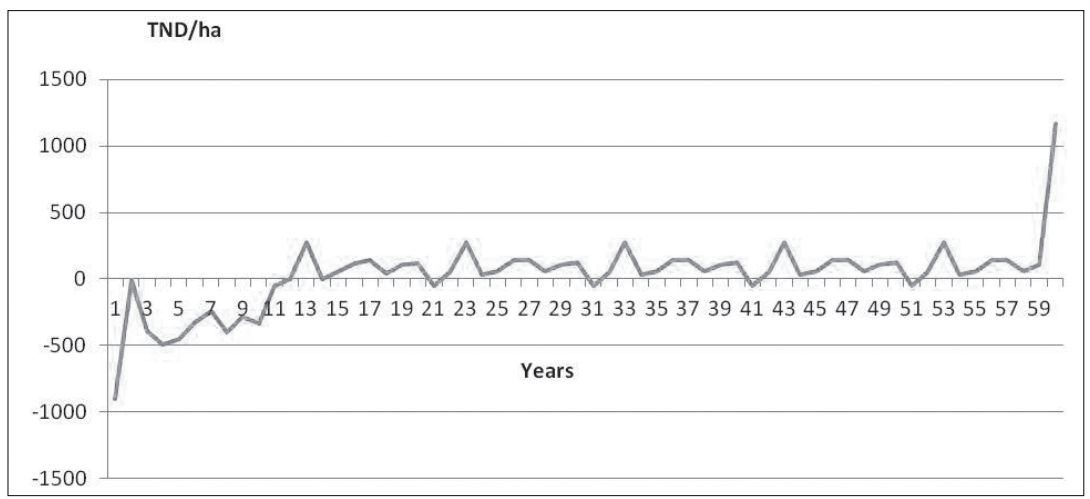

Figure 3 - Evolution of net benefits of rainfed olive trees plantation, from the farmers' perspective.
These results do not change significantly with the $\mathrm{CC}$ scenario. Assuming an additional irrigation due to CC, the NPV of irrigated olive tree plantation decreases from $6183 \mathrm{TND} /$ ha to 5069 TND/ha from the social perspective. From the global perspective, NPV values are relatively higher due to carbon sequestration. The social NPV of irrigated olive tree plantation over its life duration would decrease by $26 \%$ under the $\mathrm{CC}$ scenario, but it remains profitable as long as society can afford to continue irrigating. Even if we assume that the groundwater level would decline in future, the NPV of the subsidized irrigated olive production remains positive for farmers (4582 TND/ha).

Our results suggest that irrigated olive production around Zoghmar is likely to continue expanding as long as the subsidy remains available. Unfortunately, the analysis of social benefits and costs so far could not fully consider the risk of the drying of the groundwater table in the future. Therefore, it was not possible to assess its consequences, not only for olive production, but also for the availability and quality of water supplies to the families living in Zoghmar village.

\section{Discussion}

To our knowledge, comparative social and global benefit-cost assessments have not previously been applied in the southern mediteranean rangelands - even to the quite limited adaptation options that we have explored. Thus, the present study has set a useful precedent for encouraging Tunisian decision-makers to take such assessments into consideration.
In other rangelands where there are agroforestry solutions being advocated for adaptation to climate change, and a lack of benefit-cost assessments, decision-makers may also find our methodological approach of interest. The aspects of interest in our study include both its feasibility and applicability. And also the considerable gaps that we have identified in need of further consideration for a full assessment of the global, social and private benefits and costs of investments in agroforestry.

\subsection{Gap between private and social profita- bility}

Economic incentives are needed to fill the gap between private profitability and public utility, thus to encourage private owners to implement adaptation options that are beneficial to society. The results reported in this paper confirm the need for incentives to encourage the use of cactus in alley cropping by offering support to farmers in the first year because this intervention will only be profitable for them over the longer term. However, such incentives should not be offered for rainfed olive tree plantations because these induce a net loss for society. Also, subsidies are not justified for irrigated olive tree plantation since farmers would conduct this intervention even without any incentives.

\subsection{Research needed to consider other ex- ternatlities affecting social profitability}

There are some aspects of the social cost of irrigated tree production that we could not as- 
sess. For example, we were not able to fully assess the possible future social and private costs of depletion of water storage and reductions in water quality. We were also unable to assess the benefits of soil conservation (other than through the value of the productive output). However, these are significant concerns in our case study area. Conversion of rangelands to olive tree plantation on a slope can have negative effects in erosion of downstream areas and sedimentation of hill lakes. By contrast, the conversion of barley cropping to cactus plantation impacts positively on the society in terms of protection of agricultural lands and reduced sedimentation.

There is a need for multidisciplinary research that uses different models for the evaluation of different social costs and benefits, especially related to possible effects of cactus and olive on runoff and water table recharge. A range of other biophysical modeling techniques could help us to refine the estimates of the future effects of climate change, effects on crop production, and others (see e.g. Fader et al., 2015). Therefore improved knowledge is required, through coupling biophysical-models to economic-models, to develop decision support systems to consider different risks and uncertainties. To enable the necessary investment in these types of research, decision-makers would need to understand the difference that this knowledge could make to their benefit-cost assessments, and to farmers' livelihoods.

Where and how to invest in improving and applying the knowledge bases to assess and support the adaptations of societies in marginal rangeland areas is ultimately a political and social choice for decision-makers.

\subsection{Sensitivity analysis of profitability}

In order to determine the possible effects of other factors on our estimates, and to prioritize the various available ways to refine them further, a detailed sensitivity analysis could be explored. This could examine for example the effects of possible climate changes on the future production of different crops, the survival rate of young plantations, future variations of prices (including carbon), increases in water required for irrigation and the natural events (e.g. drought, windstorms and diseases), effects on the water balance, and possible degradation of water quality.

As we have noted early in the paper, and in the results presented, the choice of the discount rate is important in estimating the present value. A small change in the discount rate could affect the result of our calculations of social and global benefits more than several years of investment in generating climate scenarios and crop water response modeling would do.

\section{Conclusion}

In rangelands, the benefits and costs of treebased adaptations to climate change vary, depending on perspective: whether private, social or global. Many of these benefits and costs can be assessed. However, some of them cannot. And no matter how exhaustive and detailed the data and analyses from socio-economic surveys and biophysical modeling work they are based on, the final assessment can be strongly affected by methodological choices, particularly the choice of the discount rate.

Although cost-benefit assessments should be handled with care, they are useful as a discursive tool for decision-support purposes. The results of this study show that in Zoghmar village: i) rainfed olive tree plantation is not profitable, neither from the farmer perspective nor from the social perspective, ii) irrigation technology is considered as the best adaptation alternative from the farmers' perspective, but better information is needed to assess the damages related to the degradation of water resources, and iii) olive tree production does not require public subsidy - since it is already profitable from the private perspective if irrigated, but may have more social costs than we are yet able to assess.

In contrast, cactus secures additional benefits and is more attractive for individuals and society. In other rangelands where there are agroforestry solutions being advocated for adaptation to climate change, and a lack of cost-benefit assessments, decision-makers may find our methodological approach of interest. 


\section{Acknowledgments}

This study was funded, in part, by the United States Agency for International Development (USAID), "Water and Livelihood Initiative" managed by the International Center for Agricultural Research in Dry Areas (ICARDA). Authors are grateful to Dr Hichem Ben Salem, Dr Hatem Cheikh Mohamed and Dr Alva Ashok for valuable comments on the earlier version of this manuscript.

\section{References}

Alary V., Nefzaoui A., Jemaa M.B., 2007. Promoting the adoption of natural resource management technology in arid and semi-arid areas: Modelling the impact of spineless cactus in alley cropping in Central Tunisia. Agricultural Systems, 94: 573-585.

Alavalapati J.R.R., Mercer D.E., 2005. Valuing Agroforestry Systems: Methods and Applications. Nair P.K.R. (ed), New York.

Alfieri S.M., Riccardi M., Menenti M., Basile A., Bonfante A., de Lorenzi F., 2018. Adaptability of global olive cultivars to water availability under future Mediterranean climate. Mitigation and Adaptation Strategies for Global Change, 3: 1-32.

Alrusheidat J., Aljaafreh S., Abu Hammour W., 2016. Climate change adaptation and technology transfer: the path to disaster risk reduction in the arid and semi-arid zones. The case of Jordan. New Medit, 15(1): 2-6.

Banias G., Achillas C., Vlachokostas C., Moussiopoulos N., Stefanou M., 2017. Environmental impacts in the life cycle of olive oil: a literature review. Journal of the Science of Food and Agriculture, 97: 1686-1697.

Barbier E.B., 2000. The economic linkages between rural poverty and land degradation: some evidence from Africa Agriculture. Ecosystems and Environment, 82: 355-370.

Ben Rouina B., Trigui A., d'Andria R., Boukhris M., Chaïeb M., 2007. Effects of water stress and soil type on photosynthesis, leaf water potential and yield of olive trees. Australian Journal of Experimental Agriculture, 47: 1484-1490.

Ben Zaied Y., Zouabi O., 2016. Impacts of climate change on Tunisian olive oil output. Climatic Change, 139: 535-549.

Braimoh A., 2012. Assessing the carbon benefits of improved land management technologies. In Report $\mathrm{N}^{\circ} 68189$.
Branca G., Lipper L., Sorrentino A., 2015. Cost-effectiveness of climate-related agricultural investments in developing countries: A case study. New Medit, 14(2): 4-12.

Chambwera M., Heal G., Dubeux C., 2014. Economics of Adaptation, In IPCC WGII AR5 (ed).

Chaudhury A.S., Helfgott A., Thornton T.F., Sova C., 2016. Participatory adaptation planning and costing. Applications in agricultural adaptation in western Kenya. Mitig Adapt Strateg Glob Change, 21: 301-322.

Daly-Hassen H., Pettenella D., Ahmed T.J., 2010. Economic instruments for the sustainable management of Mediterranean watersheds. Forest Systems, 19: 141-155.

Fader M., Von Bloh W., Shi S., Bondeau A., Cramer W., 2015. Modelling Mediterranean agro-ecosystems by including agricultural trees in the LPJmL model. Geoscientific Model Development, 8: 35453561.

FAO 56., 1998. Crop evapotranspiration: Guidelines for computing crop water requirements, FAO Irrigation and Drainage, $\mathrm{N}^{\circ}$ 56. Allen R. et al. (ed), Rome.

FAO, 2005. Realizing the economic benefits of agroforestry: experiences, lessons and challenges. State of the world's forests, FAO, Rome.

Fleskens L., Stroosnijder L., Ouessar M., Graaff J.D., 2005. Evaluation of the on-site impact of water harvesting in southern Tunisia. Journal of Arid Environments, 62: 613-630.

Genin M., Alifriqui M., Fakhech A., Ouahmane L., Genin D., 2017. Back to forests in pre-saharan Morocco? When prickly pear cultivation and traditional agropastoralism reduction promote argan tree regeneration. Silva Fennica, 51: 1-22.

GIZ, 2007. Stratégie nationale d'adaptation de l'agriculture tunisienne et des écosystèmes aux changements climatiques. Tunis: République Tunisienne Ministère de l'agriculture et des ressources hydrauliques.

GIZ, 2012. Bilan des ressources et usages en eau du Gouvernorat de Sidi Bouzid dans un contexte de changement climatique. Tunis: Ministère de l'Environnement.

Gracia C., Vanclay J., Daly-Hassen H., Sabaté S., Gyenge J., 2011. Securing Water for Trees and People. In Birot Y. et al. (eds). Water for Forests and People in the Mediterranean Region. Helsinki, European Forest Institute, 83-91.

Grami D., Ben Rejeb J., 2015. Impact of climate change on grain farming yield in a northwestern region of Tunisia (Béja). New Medit, 14(4): 36-41. 
Guevara J.C., Estevez O.R., Stasi C.R., 1999a. Cost-benefit analysis of cactus fodder crops for goat production in Mendoza, Argentina. Small Ruminant Research, 34: 41-48.

Guevara J.C., Estevez O.R., Stasi C.R., 1999b. Economic feasibility of cactus plantations for forage and fodder production in the Mendoza plains (Argentina). Journal of Arid Environments, 43: 241-249.

Guillaume H., 2009. Mutations agropastorales, ruralité dans le sud-est tunisien. In Bonte P. et al. (ed). Développemenr rural, environnement et enjeux territeraux. IRD Éditions/Cérès Éditions, 19-43.

Hagen K.P., 2009. Project profitability from society's point of view. Making essential choices with scant information: front-end decision making in major projects. Bassingstoke, UK: Palgrave Macmillan, 390-412.

Hamrick K., Goldstein A., 2016. Raising Ambition: State of Voluntary carbon markets. Washington, DC: Forest trends' Ecosystem Marketplace.

Hanley N., Barbier E.B., 2009. Pricing Nature: CBA and environmental policy. Cheltenham, UK: Edward Elgar.

Hellegers P., Zilberman D., Ierland E.V., 2001. Dynamics of agricultural groundwater extraction. Ecological Economics, 37: 303-311.

ICARDA, 2005. Elaboration du plan de développement participatif de la Communauté de Zoghmar. Tunis: Projet Mashreq/Maghreb, Institut National de la Recherche Agronomique de Tunisie.

INRAT, 1999. Annual report 1998-1999: The development of integrated crop/livestck production in low rainfall areas of WANA (Maghreb/Mashreq).

INS, 2012. National statistical yearbook of Tunisia 2012.

IPCC, 2014. Climate Change 2014: Impacts, Adaptation, and Vulnerability. In Assessment Report 5, eI. P.O.C. Change (ed), Yokohama.

Jemaa T., Huguenin J., Moulin C.H., Najar T., 2016. Les systèmes d'élevage de petits ruminants en Tunisie Centrale: stratégies différenciées et adaptations aux transformations du territoire. Cah. Agric., 25: 1-9.

Jones P.G., Thornton P.K., 2013. Generating downscaled weather data from a suite of climate models for agricultural modelling applications. Agricultural Systems, 114: 1-5.

Kossoy A., Peszko G., Oppermann K., Prytz N., Klein N., Blok K., Lam L., Wong L., Borkent B., 2015. State and Trends of Carbon Pricing 2015. Washington DC: World Bank.

Kurukulasuriya P., Rosenthal S., 2013. Climate change and agriculture: a review of impacts and adaptations.
In Environment department papers no. 91. Climate change series. Washington DC: World Bank.

Lasco R.D., Delfino R.J.P., Catacutan D.C., Simelton E.S., Wilson D.M., 2014. Climate risk adaptation by smallholder farmers: The roles of trees and agroforestry. Current Opinion in Environmental Sustainability, 6: 83-88.

Le Houérou H.N., 1990. Agroforestry and sylvopastoralism to combat land degradation in the Mediterranean Basin: old approaches to new problems. Agriculture, Ecosystems and Environment, 33: 99-109.

Le Houérou H.N., 2000. Utilization of Fodder Trees and Shrubs in the Arid and Semiarid Zones of West Asia and North Africa. Arid Soil Research and Rehabilitation, 14: 101-135.

Lhomme J., Mougou R., Mansour M., 2009. Potential Impact of Climate Change on Durum Wheat Cropping in Tunisia. Climatic Change, 96: 549-564.

MAF, 2004. Livestock production gains from improved drinking water: literature review. In MAF technical paper no. 2004/07: 1-40.

Mazhar M., Arif A., El Mzouri L., 2002. Cactus protects soil and livestock in Rhamna region. In Proc 4th IC on Cactus Pear and Cohineal. Hammamet, Tunisia ISHS: 329-332.

MESD, 2015. United Nations framework convention on climate change: intended nationally determined contribution. Ministry of Environment and Sustainable Development of Tunisia.

Mohamad R.S., Verrastro V., Cardone G., Bteich M.R., Favia M., Moretti M., Roma R., 2014. Optimization of organic and conventional olive agricultural practices from a Life Cycle Assessment and Life Cycle Costing perspectives. Journal of Cleaner Production 70: 78-89.

Nefzaouí A., Zidani M.N., 1987. Les sous-produits de l'olivier. Institut de L'Olivier, Sfax, Tunisie.

Ouled Belgacem A., Louhaichi M., 2013. The vulnerability of native rangeland plant species to global climate change in the West Asia and North African regions. Climatic Change, 119: 451-463.

Paul C., Weber M., Knoke T., 2017. Agroforestry versus farm mosaic systems - Comparing land-use efficiency, economic returns and risks under climate change effects. Science of the Total Environment, 587: 22-35.

Sghaier M., Ouessar M., Ouled Belgacem A., Taamallah H., Khatteli H., 2010. Case of olive production sector in the governorate of Médenine. In Patterns of vulnerability in the agriculture and water sector in the southern region of Tunisia, 59. IRA/GIZ.

Sgroi F., Foderà M., Di Trapani A.M., Tudisca S., Testa R., 2015. Cost-benefit analysis: A comparison 
between conventional and organic olive growing in the Mediterranean Area. Ecological Engineering, 82: 542-546.

Stern N., 2006. Stern Review on the Economics of Climate Change. London: HM Treasury.

Stillitano T., De Luca A.I., Falcone G., Spada E., Gulisano G., Strano A., 2016. Economic profitability assessment of mediterranean olive growing systems. Bulgarian Journal of Agricultural Science, 22 (4): 517-526.

TEEB, 2010. The Economics of Ecosystems and Biodiversity for Local and Regional Policy Makers. H Wittmer (ed). London and Washington: Earthscan.

Trærup S., Stephan J., 2015. Technologies for adaptation to climate change. Examples from the agricultural and water sectors in Lebanon. Climatic Change, 131: 435-449.

Verner D., Breisinger C., 2013. Economics of Climate Change in the Arab World - Case Studies from the
Syrian Arab Republic, Tunisia and Yemen. Washington DC: World Bank.

Watkiss P., Hunt A., Blyth W., Dyszynski J., 2015. The use of new economic decision support tools for adaptation assessment: A review of methods and applications, towards guidance on applicability. Climatic Change, 132: 401-416.

World Bank, 2010. World Development Report 2010: Development and Climate Change. https:/openknowledge.worldbank.org/handle/10986/4387 License: CC BY 3.0 IGO.

Zdruli P., 2014. Land resources of the Mediterranean: Status, pressures, trends and impacts on future regional development. Land Degradation and Development, 25: 373-384.

Zouabi O., Peridy N., 2015. Direct and indirect effects of climate on agriculture: an application of a spatial panel data analysis to Tunisia. Climatic Change, 133: 301-320. 